\title{
Next Trial Identification
}

National Cancer Institute

\section{Source}

National Cancer Institute. Next Trial Identification. NCI Thesaurus. Code C83076.

The identifier of the subsequent trial that the patient is entering. 